\title{
西日本談話会
}

\section{Report of Nishi-nihon Branch}

平成16年 4 月から「西日本談話会」の世話人を鹿毛浩 之先生（九工大・工）から筆者が引き継ぎ, 現在に至っ ている。

「西日本談話会」は九州・中国地方（主に広島以西） の会員を対象亡して, 通常年 2 回 (夏と年末), 九州工 業大学戸畑キャンパスを会場として開催されている。例 年, 夏（第 1 回目）は 3 名程度の講師の先生を招いて行 なう粉体工学に関する講演会で，年末（第 2 回目）は西 日本地区の粉体工学の研究者が集まって気軽に討論でき るよう取り計らったシンポジウム形式の会合である。年 末に開催される第 2 回目の会合では，気楽な雾囲気の中 にも実質的で真剣な討論を行ってお互いに切瑳环磨して 研究のポテンシャルを高めることが目的であるため, 発 表内容にオリジナリティを求めることはせず，一人当た りの討論時間を十分長く取るように心掛けている。すな わち講演 1 件当りの持ち時間は20分〜30分で，発表時間 を10分〜15分とし討論時間もそれと同じ10分〜15分とし ている。西日本談話会は参加者が最大でも40名程度と比 較的少人数であることと, 大部分の参加者どうしが既に 顔馴染みであるため, リラックスして落ち着いた雾囲気 の中にも真摰で忌憚のない活発な討論が行われており， 前述の目的は十分達成されていると思われる。

現在の課題は，粉体工学会の会員がそれほど多くない 西日本地区では談話会の定常的なメンバー確保と増強が 常に問題となることである。特に最近の数年は長年にわ たって西日本談話会を支えて活躍してこられた多くの先 生方が相次いで定年退官を迎えられる世代交代期にあた っており，次代を担う新しい世代の研究者を西日本談話 会のメンバーとして開拓することが急務になっている。 そのための方策のひとつとして，関連学協会との相互交 流なども積極的に進めるようにしている。

参考データとして平成17年度の実施状況を以下に示 す。

\section{5年度 第 1 回}

平成17年 9 月 2 日（金）13時00分～17時00分

九州工業大学（戸畑キャンパス）附属図書館本館 A V ホール，参加者 : 37名

(1)「ナノ粒子の合成，分散，自己組織化による機能材料 への応用」○奥山喜久夫（広島大・工）

(2)「機械工学, 化学工学, 成型加工, 人工肝臟, これか らの興味?

(3)「多孔質内の伝熱流動について」 ○増岡隆士（九大名誉教授）

2005年度 第 2 回（通算30回）

平成17年12月21日（水） 13 時00分～17時10分
九州工業大学 (戸畑キャンパス) 附属図書館本館 A V ホール, 参加者 : 42名

(1)「実高炉内におけるコークス粒子と気流の運動の数值 シミュレーション」

梅景俊彦, ○門脇正具 (九工大),

湯 晋一（大岳 R \& D コンサルタント事務所）

(2)「液中粒子群の沈降及び凝集過程の数值解析」

○梅景俊彦（九工大）,

湯 晋一（大岳R \& D コンサルタント事務所）,

城野祐生, 中島賢治, 里見暢子（佐世保高専）

(3)「粒子法による二軸スクリュ押出機内の材料挙動予測 技術の開発」

○梶原稔尚, 影本真也 (九大), 富山秀樹（日本製鋼所）

(4)「室内環境中の微生物粒子の捕集と検出」

○石松維世, 福田和正, 石田尾徹,

谷口初美, 保利一（産業医大）

(5)「電解反応により生成した鉄コロイド粒子の特性と有 害化学物質除去への応用」○大佐々邦久（山口大）

(6)「インクジェット法製膜法における高分子薄膜形状と 乾燥速度の関係」

○金田昌之, 酒井洋輔, 石塚博孝,

深井 潤, 高原 淳 (九大)

(7)「非平衡 R F プラズマによる非凝集ナノ粒子の合成」

林豊, ○吉野 朝,

島田 学, 奥山喜久夫（広島大）

(8)「エアレーションによる容器内粉体層の孔からの排出 に関する研究」○尾形公一郎（大島商船高専）

(9)「スタンドパイプ内を自由落下する粉体群の運動特 性」

○中島賢治（佐世保高専）,

横原 大 (三光機械)

(10)「二次元振動流動層への供給ガスの湿度および流速が 気泡に及ぼす影響」

○大村政浩, 河野宏省, 有田覀由,

馬渡佳秀, 山村方人, 鹿毛浩之（九工大）

(11)「柔らかい粒子の水平低速空気輸送について」

○麻生裕之, 古川 武,

船津勝也, 富田侑嗣（九工大）

[講演順・敬称略]

なお「西日本談話会」の開催案内は粉体工学会誌会告 に掲載するとともに，希望者に対しては電子メールまた は郵送による連絡を行っています。この記事をご覧にな って「西日本談話会」の活動に関心を持たれた方は世話 人までご連絡ください。

(九州工業大学 梅景俊彦) 